\title{
Characterization of Amorphous Silica and Crystalline Silica From Rice Husk Ash on Water Filtration Application
}

Nur Saadah Zainal ( $\sim$ Whaddup17@gmail.com )

Tun Hussein Onn University of Malaysia: Universiti Tun Hussein Onn Malaysia

\section{Zaleha Mohamad}

Universiti Tuh Hussein Onn Malaysia, 86400 Parit Raja, Johor, Malaysia.

\section{Mohammad Sukri Mustapa}

Universiti Tuh Hussein Onn Malaysia, 86400 Parit Raja, Johor, Malaysia.

Nur Azam Badarulzaman

Universiti Tuh Hussein Onn Malaysia, 86400 Parit Raja, Johor, Malaysia.

\section{Research}

Keywords: Rice husk ash, amorphous, crystalline, silica, water filtration, applications

Posted Date: October 21st, 2020

DOI: https://doi.org/10.21203/rs.3.rs-93294/v1

License: (c) (i) This work is licensed under a Creative Commons Attribution 4.0 International License. Read Full License 


\title{
Characterization of Amorphous Silica and Crystalline Silica from Rice Husk Ash on Water Filtration Application
}

\author{
Nur Saadah Zainal ${ }^{1, *}$, Zaleha Mohamad ${ }^{2}$, Mohammad Sukri Mustapa ${ }^{3}, N_{u r}$ Azam Badarulzaman ${ }^{4}$ \\ Faculty of Mechanical and Manufacturing Engineering, Universiti Tun Hussein Onn Malaysia (UTHM), \\ Johor, Malaysia
}

whaddup17@gmail.com*, zaleha@uthm.edu.my, sukri@uthm.edu.my, azam@uthm.edu.my

*corresponding author

\begin{abstract}
The presence of water pollution which consists of heavy metals, fecal and others has produced a major problem. These can lead the water to the toxicity and the impurity of water will be disrupted. Therefore, it would not be safe to drinks and could be threatening to live health. In addition, the current market now is dealing with

best option to support the objective by $98.60 \%$ silica content, $64.82 \%$ of porosity, 1.1433 $\mathrm{mg} / \mathrm{cm}^{3}$ of density, $40.59 \%$ of water absorption, and $\mathrm{pH}$ of 7.62 of water after filtration. In general, the quality of the ceramic filter membrane is reliant on the raw material, while the water clarity is dependent on the pore size of the filter membrane.
\end{abstract} high-cost production to develop ceramic membranes and has been using expensive material to make the filtration system works. In order to challenge the issue, the preparation of ceramic water filtration at low-cost production and using an effectively silica from natural waste rice husk was evaluated. Rice husk was fired at $700^{\circ} \mathrm{C}$ and $1000^{\circ} \mathrm{C}$ respectively and produced rice husk ash which mutated to amorphous and crystalline silica. Five samples were fabricated after been mixed with the compositions of rice husk ash, kaolin clay, and wheat flour, used at 40:40:20 ratios by weight respectively. The fabrications of the ceramic membrane were conducted by using dry pressing. The samples then were dried in the oven at $60^{\circ} \mathrm{C}$ for 1 hour followed by sintering at $1000^{\circ} \mathrm{C}$ respectively. These samples (OO, C1, C2, N1, and N2) were tagged based on unwashed and washed material with the chemical. The properties of silica which the microstructure and pore size, from rice husk ash were obtained by using X-Ray Fluorescence (XRF) and $x$-ray diffractometer (XRD). Effect of silica content in ceramic filtration membrane was investigated and characterized in term of porosity, density, water absorption, pore size, the turbidity of water (before and after filtration) and $\mathrm{pH}$ value. From the result, sample $\mathrm{C} 2$ was the

Keywords: Rice husk ash, amorphous, crystalline, silica, water filtration, applications

\section{Introduction}

The increase in industrial activities has greatly affected the changes in ecosystems which this has affected to the threat of environmental health of humans. Among the many cases of pollution, the contamination of water ranks the highest place. Thus, to reduce the health and disease issues, water purification needs to be done by using the water filter. It is impossible to remove $100 \%$ of fecal, but there is a way of minimizing the contamination of water. There are a few possible ways which are a physical barrier, chemical process or a biological process by filtering the water to residue a cleanse for a resolution. For examples, providing agricultural drainage system, save in drinking water, protected from waterborne disease and the safe use of ponds and swimming pools.

One of the environmental sustainability targets is recycled back the agricultural waste products [1]. The agricultural waste products will be used in water treatment and if well entrenched, it will be useful to those in the poor communities. 
According to the statistics compiled by the Malaysian Ministry of Agriculture, 408,000 metric tonnes of rice husk is produced in Malaysia each year [2]. The rice industry produces substantial amounts of waste materials. Most of the waste materials originated in the rice production cycle which includes rice husk, rice straw, and rice husk ash. Rice husk is the external of the rice seed layer, removed during the grinding process. For every 4 tons of harvest rice, about 1 ton of rice husk is produced which is about $20 \%$ to $30 \%$ of the grain weight. Rice straw is the stem of the plant that sinistrial as the remainder in the field, after harvesting the grain. For each kilo of paddy rice about $0.41-3.96 \mathrm{~kg}$ of rice straw are assembled [3].

Rice husks are the hard-defensive covers of grains of rice and they are eliminated from rice seeds as a side stream during the processing cycle. Rice husk are mainly composed by three polymers (cellulose, hemicelluloses and lignin) which could be utilized as a value-added raw material for various purposes [4]. The valorization of this side stream could not only solve the removal issue yet could also decrease the expense of waste treatment and make new commercial openings [5]. One potential use for rice husk valorization is to consume it as fuel for vitality and vapor production. When rice husk is incinerated the ash obtained during the process is called rice husk ash which can be used as land filling. This material is also very easy to obtain and requires a low cost. The silica content found in rice husk is widely used in electronics, ceramics, plastic, rubber, and photoelectric industries. Silica from the rice husk has been used as a heat exchanger agent and composite additives [6].

Rice husk ash has become a source for the preparation of rudimentary silicon and silica because of its high silicon content. It is also a source of activated carbon and it is tested as an adsorbent material [7]. As to utilization of rice husk ash as an adsorbent previous work endeavours are focused on water treatment, due to the large amount of available material and its low cost compared to commercial adsorbents [8].
This concept has likely advantages on both water treatment and waste management.

Today in the market stream, although synthetic silica content has been used extensively, the use of silica from natural materials is still relevant due to its low cost and environmentally friendly. Silica that present from the husked rice is used to enhance the production of existing filter since the worldwide annual rice husk output is about 80 million tones and over $97 \%$ of the husk is generated in the developing countries. Malaysia is one of them.

Fabrication of water filter from this natural waste resource could help to reduce water pollution in Malaysia and offer a healthier life. The presence of several water filters made of ceramic materials in the market shows the potential of it to clean and strain the unwanted substances.

But, there are a few problems with the current water filters that available in the market. Water filter is used in almost every house and has benefited many users. However, water filters that available in the market are very expensive, while there are still many people who cannot afford to have a quality water filters especially for those who live in rural and urban areas. In fact, there are societies that still rely on water from rivers and wells. Moreover, the quality of water in state of odour, impurity and contaminant also are possible problems to look. Therefore, in this work, the water filter has to fill the requirements by improving the granular structure, chemical stability, and local availability at almost no cost to improve the quality of water.

Therefore, this research aims to study and investigate the potential of Silica (SiO2) used in the water filter filtration. The research methodology has been conducted in accordance with the established standards.

\section{Material and Method}

The rice husk was washed using tap water to remove unwanted substances. Then to make sure the rice husk was utterly dried, it has been placed under the sun for 48 hours. Afterwards, for sample CS1 and AS 1, there 
undergone for chemical treatment. Firstly, the cleaned rice husk was treated separately with hot hydrochloric acid at $60^{\circ} \mathrm{C}$ at concentration of $0.5 \mathrm{M}$ for 30 minutes with constant stirring. After the acidic solution was drained off, the rice husk was rinsed with distilled water until it free from acids, filtered and dried in air-oven at $110^{\circ} \mathrm{C}$ for 24 hours. Then, the rice husk was incinerated in a furnace at $700^{\circ} \mathrm{C}(\mathrm{AS} 1$ and $\mathrm{CS} 1)$ and $1000^{\circ} \mathrm{C}$ (AS2 and CS2) for 2 hours. The heating rate used was $5^{\circ} \mathrm{C} / \mathrm{min}$.

The produced rice husk ash under nonchemical treatment was called CS 2 and AS2. The process started to take place by heating in a furnace with the same temperature, holding time and heating rate. Later, the sieving process took place by passed through $63 \mu \mathrm{m}$ mesh sieve. Subsequently, the rice husk ash undergone XRF and XRD to find the phases of silica oxide when firing at $700^{\circ} \mathrm{C}$ and $1000^{\circ} \mathrm{C}$ [9]. For the ceramic filtration membrane, the process took place by mixing the amorphous and crystalline silica with the binder and shaped it by using compaction process by using pressing machine. After a dry pressing process, the sample is dried at a temperature of $60^{\circ} \mathrm{C}$ for 1 hour. Temperature for the sintering process has been performed at $1000^{\circ} \mathrm{C}$ using furnace. the heating rates is $2^{\circ} \mathrm{C} / \mathrm{min}$ from room temperature until $600^{\circ} \mathrm{C}$ and kept constant for 2 hours then continue heating until reach $1000^{\circ} \mathrm{C}$ with heating rate $3^{\circ} \mathrm{C} / \mathrm{min}$ and kept constant for 3 hours. These two different sintering temperatures for sintering and heating rates is needed to obtain a uniform combustion for all the samples. To find the hardness value, the sample then undergone hardness testing by using microhardness tester machine [10].

\section{Characterization}

\subsection{X-Ray fluorescence (XRF)}

$\mathrm{X}$-Ray fluorescence is particularly wellsuited for investigations that involve bulk chemical analyses of major elements ( $\mathrm{Si}, \mathrm{Ti}, \mathrm{Al}$, $\mathrm{Fe}, \mathrm{Mn}, \mathrm{Mg}, \mathrm{Ca}, \mathrm{Na}, \mathrm{K}$ ) in rock and sediment.

\subsection{X-Ray Diffraction (XRD)}

$\mathrm{X}$-ray Diffraction is a rapid analytical technique used for phase identification on unit cell dimensions. For a general overview, the speed of $\mathrm{x}$-ray is set at fast speed. Samples were scanned from 2 hours from $2 \theta$ ranging from $5^{\circ}$ to $90^{\circ}$. The EVA ${ }^{\mathrm{TM}}$ Software was used to record and analyze the structural pattern of the samples.

\subsection{Porosity and Density Test}

The porosity test is done to obtain the percentage of the porosity within the sample. It is done by the simple technique by using Porosity Weight Scale (Metter Tuledo). This test is followed to the standard test methods of ASTM C20-00.

\subsection{Turbidity Test}

The turbidity test was done to determine its ability for filtration. In this test, the Blue dye was used as the molecule that is attempting to be filtered. The test was carried out a few times, to get accurate data. The test is led as the filter system has cleaned and a full setup. The Blue dye is dissolved in the container that contains raw water. After the solution is filled with raw water vessel of the filter system and left 1 to 2 hours to let the water passes through the filter membrane and come out as treated water. The treated water at that point is observed physically (turbidity).

The observation was done with bare eyes without any visual aid. If the treated water is clear, this implies the filter component is prevailing the success in clog up the Blue Dye molecule. If the treated water demonstrates the lightly or intensely shading, the capacity of the channel component can be doubtful. At any rate, this is the simple test to find the ability of the filtration element of the ceramic water filter.

\section{5 pH Test}

$\mathrm{pH}$ test is a test that a tries to identify the perusing of the water after filtration of amorphous and crystalline silica filtration film is finished. $\mathrm{pH}$ meter is utilized as a device to recognize the reading of $\mathrm{pH}$ test. This testing is very important in order to produce water filtration and the value of $\mathrm{pH}$ result must 
implement with the Drinking Water Quality Standard that was set by Ministry of Health which is between 6.5- 9.0 and there is no unit for this result [11].

\section{Results and Discussion}

\subsection{Analysis on X-Ray fluorescence (XRF)}

$\mathrm{XRF}$ is based on the rule that individual molecules, excited by an external energy source, discharge X-beam photons of a characteristic energy or wavelength. By checking the number of photons of every vitality transmitted from a sample, the elements present might be distinguished and quantitated. Table 1 shows the element contained in all five samples.

Table 1. Element contained in samples.

\begin{tabular}{c|c|c|c|c|c}
\hline \multirow{2}{*}{ Formula } & \multicolumn{5}{|c}{ Concentration (\%) } \\
\cline { 2 - 6 } & $\begin{array}{c}\text { Sample } \\
\mathrm{OO}\end{array}$ & $\begin{array}{c}\text { Sample } \\
\mathrm{N} 1\end{array}$ & $\begin{array}{c}\text { Sample } \\
\mathrm{C} 1\end{array}$ & $\begin{array}{c}\text { Sample } \\
\mathrm{N} 2\end{array}$ & $\begin{array}{c}\text { Sample } \\
\mathrm{C} 2\end{array}$ \\
\hline Orig-g & 8 & 8 & 8 & 8 & 8 \\
\hline added-g & 2 & 2 & 2 & 2 & 2 \\
\hline $\mathrm{SiO}_{2}$ & 63.30 & 77.90 & 81.00 & 95.70 & 98.60 \\
\hline $\mathrm{CaO}$ & 11.70 & - & 10.00 & - & - \\
\hline $\mathrm{C}$ & 0.10 & 0.10 & 3.13 & - & - \\
\hline $\mathrm{K}_{2} \mathrm{O}$ & 3.70 & 3.96 & 2.02 & 0.30 & 0.1 \\
\hline $\mathrm{P}_{2} \mathrm{O}_{5}$ & 2.95 & 2.89 & 81.00 & - & - \\
\hline $\mathrm{MgO}^{2}$ & 1.28 & 0.98 & 0.74 & - & 0.20 \\
\hline $\mathrm{SO}_{3}$ & 0.96 & 0.98 & 0.36 & - & - \\
\hline $\mathrm{Al}_{2} \mathrm{O}_{3}$ & 0.72 & 0.48 & & 2.60 & - \\
\hline $\mathrm{Cl}^{2}$ & 0.62 & 0.14 & 0.10 & - & - \\
\hline $\mathrm{Na}_{2} \mathrm{O}$ & 0.33 & - & - & - & - \\
\hline $\mathrm{Fe}_{2} \mathrm{O}_{3}$ & 0.28 & - & - & 0.30 & - \\
\hline
\end{tabular}

Table 1 shows the element contained in all five samples. From the result, it showed that the silica content in Sample OO was about $63.30 \%$. As for Sample N1 shows that the $\mathrm{SiO}_{2}$ content is about $81.00 \%$ while for Sample N2, the silica is about $95.70 \%$. Lastly, the silica content for Sample C2 is about 98.60\%. Therefore, if compared with NI, the chemical addition is definitely changed the silica contained.

The major components of rice husk are organic materials such as hemicellulose, cellulose and lignin totalling about $75 \%$ to $90 \%$ and the remaining ash content of $17 \%-20 \%$. The ash mainly consists of less than $90 \%$ silica and some metallic impurities. Combustion of rice husk under controlled conditions leads to the productions of rice husk ash containing almost pure silica. The metallic impurities such as iron $(\mathrm{Fe})$, manganese $(\mathrm{Mn})$, calcium $(\mathrm{Ca})$, sodium $(\mathrm{Na})$, potassium $(\mathrm{K})$ and magnesium $(\mathrm{Mg})$ that influence the purity and color of the silica were eliminated by pre-treatments with hydrochloric acid prior to combustion.

It has been reported that at $600^{\circ} \mathrm{C}$ to $1000^{\circ} \mathrm{C}$ and depending on the time of combustion, amorphous silica is formed, but at higher temperature, crystalline silica is obtained. In this systematic study, the higher temperature and treated with chemical treatment produced high contained of Silica.

Thus, the rise in the cellulose fibres crystallinity was expected to increase the rigidity, stiffness, and strength. It can be presumed that the potential mechanical properties and strengthen capability of treated fibres increased [12].

\subsection{Analysis on X-Ray Diffraction (XRD)}

The porosity test is done to obtain the percentage of the porosity within the sample. It is done by the simple technique by using Porosity Weight Scale (Metter Tuledo). This test is followed to the standard test methods of ASTM C20-00.

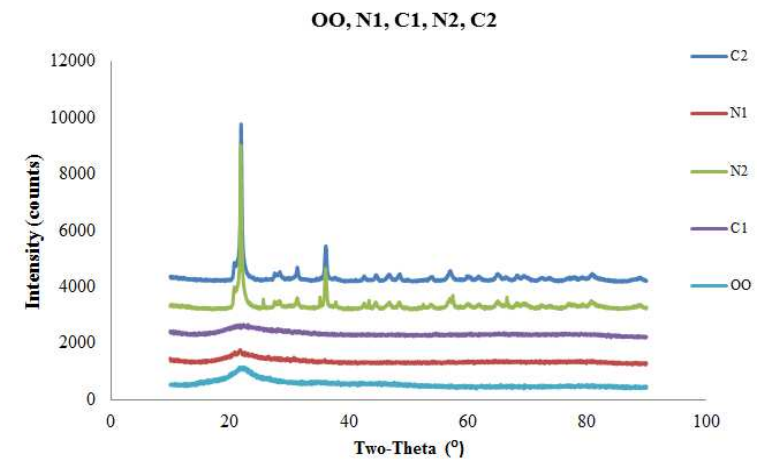

Fig. 1. X-ray Diffraction (XRD) analysis result for samples.

The Figure 1 demonstrates the graph of the chart investigation of X-Ream Diffraction for five samples. Sample OO and N1 show that there is only one single peak and definitely at highly amorphous silica. The reflection peak shows for 
Sample OO is about $2 \Theta=24^{\circ}$ while Sample N1 has a reflection peak of $2 \Theta=22^{\circ}$. Moreover, Sample C1 shows that the rice husk ash is still formed a highly amorphous silica state. The reflection peak is formed about $2 \Theta=20.79^{\circ}$.

As for Sample N2 and C2, the rice husk ash is a highly crystalline structure. It can be supported by the existence of consisted of sharp reflection peak between $2 \Theta=23^{\circ}$ to $81^{\circ}$ for Sample N2 and an existed of a few peaks within $2 \Theta=23^{\circ}$ to $88^{\circ}$ for Sample C2. The Figure 2 demonstrates the graph of the chart investigation of X-Ream Diffraction for five samples. Sample $\mathrm{OO}$ and N1 show that there is only one single peak and definitely at highly amorphous silica. The reflection peak shows for Sample OO is about $2 \Theta=24^{\circ}$ while Sample N1 has a reflection peak of $2 \Theta=22^{\circ}$. Moreover, Sample $\mathrm{C} 1$ shows that the rice husk ash is still formed a highly amorphous silica state. The reflection peak is formed about $2 \Theta=20.79^{\circ}$.

As for Sample N2 and C2, the rice husk ash is a highly crystalline structure. It can be supported by the existence of consisted of sharp reflection peak between $2 \Theta=23^{\circ}$ to $81^{\circ}$ for Sample N2 and an existed of a few peaks within $2 \Theta=23^{\circ}$ to $88^{\circ}$ for Sample C 2 .

According to $\mathrm{Xu}$ et al., [13], these peaks can be assigned to cristobalite and tridymite, individually. Moreover it is important to mention that the cristobalite peak with the highest intensity represents the crystallization chemical rice husk ash particles. These result proved that by using chemical treatment and thermal treatment help to lift up the silica contained.

In a study by [14], to incinerate the rice husk, the tested has been run in various temperatures and the material previously leached ones. However, the sharpeners of the peak increase with combustion temperature start around $900^{\circ} \mathrm{C}$ and the removal of alkaline species during acid leaching is an obstacle to the eutectic reaction of silica.

\subsection{Analysis on Porosity and Density}

This test is a standard test that are required in quality control, examine and improvement, and giving information to configuration purposes. Deviation from any of these doubts inimically impacts the test results. The level of porosity was calculated inside by using specific equation from the ASTM C20-00. The sample weight is recorded in gram (g) and determined dependent on the condition of porosity and density.

Table 2 shows the result of porosity and density for five samples. From the result of water absorption, the highest scored is $43.57 \%$ which is Sample OO. The lowest value is $33.59 \%$ which is scored by Sample N2. Theoretically, this value is should be higher than Sample N2 because according to the previous researcher, Muhammadi et al. (2015), [15] is due to the stability of water pervade through the pores. As can be seen, the water particles will easily pass through the membrane pores. After certain time, the pores have been filled up with water by the monolayer formation by adsorption water atoms pursued by the condensation of water molecules within the pores and the flow of water transition through the membrane is beginning to stable [16]. This outcome was in accordance with most examinations announced in past writings too.

As for the density result shows that the highest density value stated is $1.2278 \mathrm{~g} / \mathrm{cm} 3$ which is from Sample N2. The least value is from Sample OO which is $0.8074 \mathrm{~g} / \mathrm{cm} 3$. This can be supported by the previous researcher, that the clearly permeable where enormous circular pores contained little cell pores on their internal walls [17]. The enormous circular pores were produced by mixing with a pore foaming agent, and the small cell pores on internal walls are derived from the organic matter removal and mullite particle accumulation. As sintering temperature increase, the measure of small cellular pores on the internal dividers diminished, which was brought about by sintering densification.

Moreover, for porosity result, Sample OO scored the highest value which is about 64.82\% while Sample C2 scored 53.60\%. As expected, when the sintering temperature is increased to $1000^{\circ} \mathrm{C}$, the pore size becomes larger due to the existence of particle diffusion, resulting from the silica melting phenomenon at 
a higher temperature [18]. The porosity of water filter membranes sintered at various temperatures is estimated using the formula from ASTM C2000. Furthermore, the porosity value is in line with the trend showed by the pore size distribution. It ought to be referenced that all the porosity acclaim are above $40 \%$. Honda et al. (2010) expressed that, to limit the weight drop, permeable artistic films have a generally bigger porosity of above $40 \%$ [19]. Not just that, the best porosity can achieve a high- quality standard to filtered unwanted substances that can contribute to permeability quality water after going through the filtration process.

Table 2. The result of porosity and density testing.

\begin{tabular}{c|c|c|c|c|c}
\hline \multirow{2}{*}{ Data } & \multicolumn{5}{|c}{ Sample } \\
\cline { 2 - 6 } & $\mathrm{O}$ & $\mathrm{N} 1$ & $\mathrm{C} 1$ & $\mathrm{~N} 2$ & $\mathrm{C} 2$ \\
\hline $\begin{array}{c}\text { Apparent } \\
\text { Porosity } \\
(\%)\end{array}$ & 64.82 & 60.38 & 60.00 & 58.75 & 53.60 \\
\hline $\begin{array}{c}\text { Density } \\
(\mathrm{g} / \mathrm{cm} 3)\end{array}$ & 0.81 & 1.01 & 1.03 & 1.23 & 1.14 \\
\hline $\begin{array}{c}\text { Water } \\
\text { absorption } \\
(\%)\end{array}$ & 43.57 & 39.29 & 33.59 & 38.86 & 40.59 \\
\hline
\end{tabular}

\subsection{Analysis on Turbidity Test}

Table 3 shows the Sample C1, N1, and $\mathrm{C} 2$ show the clearest water after filtration than the others. As for the Sample OO and Sample N1, the cleanliness water is absurd. Sample OO and Sample C1 recorded the lowest reading in the percentage of porosity. This is due to the deposition of a blue particle on the surface of the filter membrane. Therefore, the water difficult penetrates through the filter membrane as the pore has been plugged up by the blue particle.

In this table also showed the result of water turbidity before and after filtration. It has been run using a blue dye. The higher clarity of the water from these examples is a result of the level of pore inside the filter layer.

The level of porosity inside these examples is the most reduced among the other which causes the particle to can be separated smaller molecule.

This also demonstrates acid leaching produces a critical impact on the surface area just as pore volume of silica. The expansion in surface area of acid-leached silica is essentially credited to the hydrolysis of hemicellulose and cellulose into smaller compounds which could decompose simpler during combustion. Consequently, the high permeable structure is acquired as affirms by the expansion in pore volume [20].

Not just that, the temperature really affects the quantity of the existence of pore numbers and sizes. When the temperature increased, porosity increased slightly, but grain size and pore size became larger, which lead to the mechanism of water easily penetrate through the pore [21].

Table 3. Water (before) and (after) filtration.

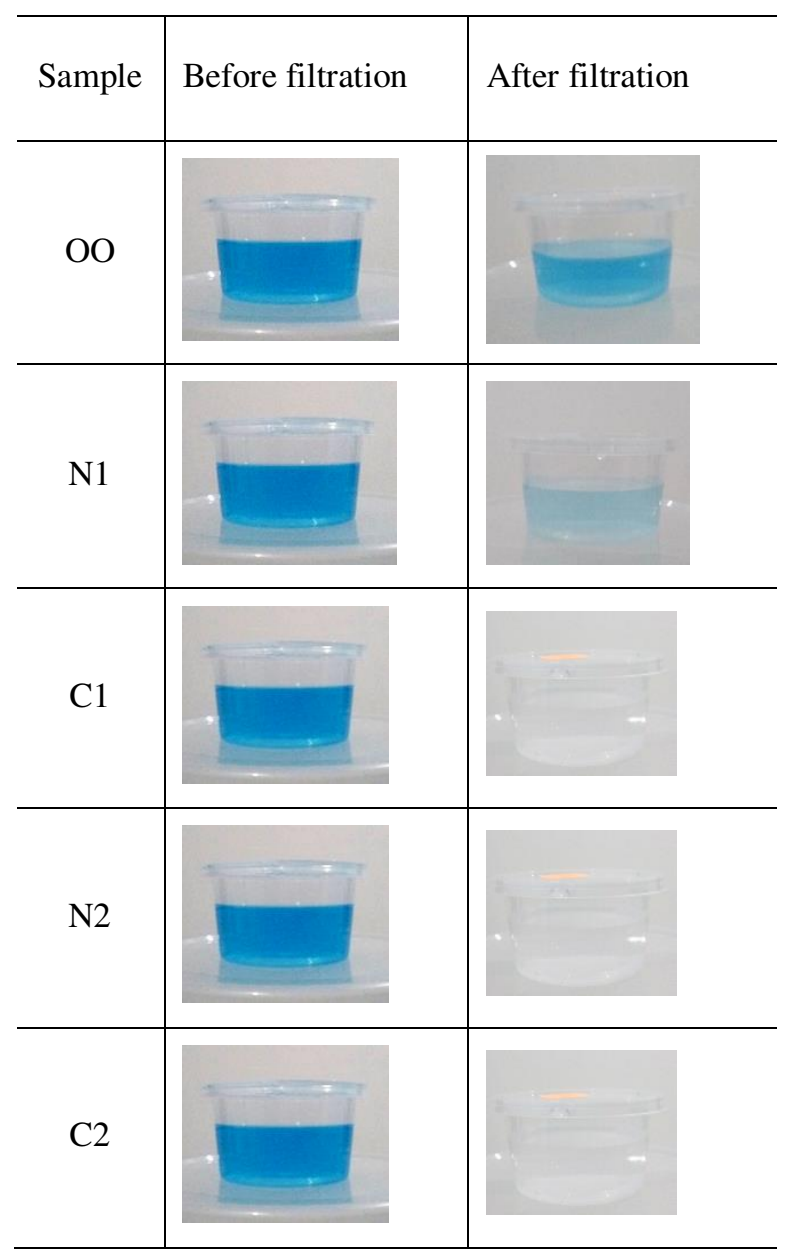

\subsection{Analysis on pH Test}

Figure 2 shows the bar chart of $\mathrm{pH}$ readings for all five samples. From the results, Sample C2 shows the best value of $\mathrm{pH}$ reading 
compared to others. But, Sample N2 is slightly a bit different with, 7.66. The other sample OO, $\mathrm{N} 1$, and $\mathrm{C} 2$ are not compatible even though still with the range from Drinking Water Quality Standard, Ministry of Health. Thus, Sample N2 and $\mathrm{C} 2$ are suitable choices.

High porosity infers there is a larger number of void spaces in the ceramic filters membrane that enables the water to go through the filter components. If there are more pores in the filter, at that water may be the move through quicker [22].

Electrical conductivity is related to the measure of particles present in a given solution [23]. Higher $\mathrm{pH}$ conditions may improve adsorption of strongly charged particles.

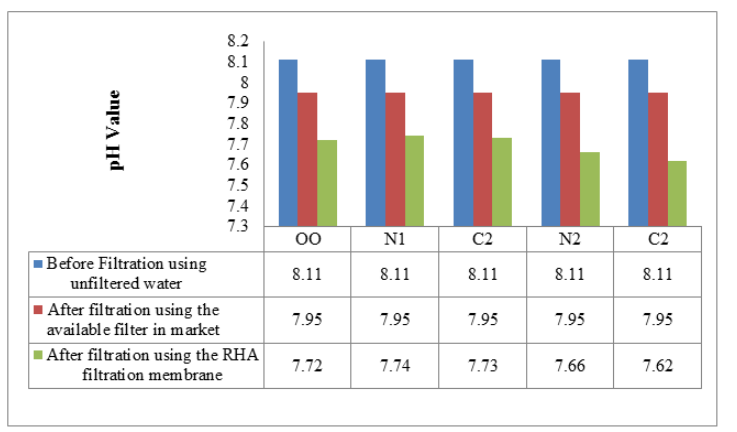

Fig. 2. Bar chart of $\mathrm{pH}$ values for samples.

\section{Conclusion}

Rice husk ash can create a different period of silica. By fired the rice husk at $700^{\circ} \mathrm{C}$, an amorphous silica stage was shaped while fired the rice husk at $1000^{\circ} \mathrm{C}$ was prompts the type of crystalline silica. Moreover, chemical treatment increased the level of silica. Bonds between the material and binder unquestionably impact the presence of pore size which leads to the mechanism of water easily penetrate through the pore. Sample C1, N2 and C2 demonstrate the cleanliness of the water. As for the $\mathrm{pH}$, higher $\mathrm{pH}$ conditions may improve adsorption of strongly charged particles.

Therefore, the objective of this study which is to create a ceramic water filter membrane on laboratory scale and to research their effectiveness of microbial content, turbidity, better quality of $\mathrm{pH}$ value and conductivity of water to study their performance and ability using inexhaustible organic resources at different terminating temperatures and compositions of the material which is rice husk are achieved.

From the result, there are two samples that supported the objective of this study which is Sample N2 and Sample C2. Sample N2 is achieved a $95.7 \%$ silica content, $58.75 \%$ of porosity, $33.59 \%$ of water absorption and $\mathrm{pH}$ of 7.66 after filtration process. Sample C2 achieved $98.60 \%$ silica content, $64.82 \%$ of porosity, $40.59 \%$ of water absorption and $\mathrm{pH}$ of 7.62 after filtration process. In this case, Sample C2 demonstrates the best contrasted with other samples.

$\begin{array}{lcr}\begin{array}{l}\text { Abbreviations } \\ \text { XRF:X-Ray }\end{array} & \text { Fluorescence, } & \text { XRD:X-Ray } \\ \text { diffractometer, } & \text { Si:Silicon, } & \text { Ti:Titanium, } \\ \text { Al:Aluminium, } & \text { Fe:Iron, } & \text { Mn:Mangenese, } \\ \text { Mg:Magnesium, Ca:Calcium, } & \text { Na:Sodium, } \\ \text { K:Potassium, ASTM:American } & \text { Society for } \\ \text { Testing and Materials. }\end{array}$

\section{Acknowledgment}

The authors would like to thank University Tun Hussein Onn Malaysia (UTHM), for providing Grant No. H672 and Nano Siltech Sdn Bhd for sponsoring this work.

\section{Authors' contributions}

This experimental work, data collection, data analysis, illustrations, and manuscript preparation were completed by Nur Saadah Zainal. Dr Zaleha Mohamad guided the idea and revised the manuscript. Assoc. Prof. Dr. Sukri Mohamad and Dr. Azam Badarulzaman are contributed in addition of knowledge. All authors read and approved the final manuscript.

\section{Authors' information}

${ }^{1}$ Nur Saadah Zainallreceived the Diploma, Bachelor degree and Master Degree in Mechanical Engineering from the University of Tun Hussein Onn Malaysia (UTHM), Malaysia in 2014, 2017 and 2020. She is currently pursuing her $\mathrm{PhD}$ in Material Science in Faculty of Mechanical Engineering, University of Tun Hussein Onn Malaysia (UTHM) and she is 
working on potentiality of rice husk silica and bamboo fibre. She is an associate member of Board of Engineering Malaysia (BEM).

${ }^{2}$ Zaleha Mohamad received the Bachelor degree in Mechanical Engineering from the Kolej Universiti Teknologi Tun Hussein Onn Malaysia (KUiTTHO) which is now has been known as a University of Tun Hussein Onn Malaysia (UTHM) in 2003. She then continued her study in Master of Mechanical Engineering (Material) from The National University of Malaysia (UKM) in 2008. In 2016, she received her PhD in Mechanical Engineering from UTHM. She did teaching in the Faculty of Mechanical Engineering in UTHM, Malaysia. She has been authored and/or co-authored various tehnical and review papers on the research in material science. Her field of expertise is at material science and technology. She is an associate member of Board of Engineering Malaysia (BEM) and International Association of Engineering (IAENG).

${ }^{3}$ Mohammad Sukri Mustapa is an Associate Professor at University of Tun Hussein Onn Malaysia (UTHM). He received his certificate in Mechanical Engineering in Polytechnic in 1992. After that, he continued his Bachelor degree in General Machinery from Institut Teknologi Tun Hussein Onn (ITTHO), Malaysia as for now has been known as UTHM in 1997. Since, his passion in Mechanical Engineering, he continued his study in Diploma and Master in Mechanical Engineering from ITTHO from 1999 and 2002. $\mathrm{He}$ received his $\mathrm{PhD}$ in Material Science Engineering from Nagaoka University of Technology in Japan in 2010. He did teaching in the Faculty of Mechanical Engineering in UTHM, Malaysia. He has been authored and/or co-authored various technical and review papers on the research in material science. His fields of expertise are fatigue of material and structural integrity of metal and nature fiber. $\mathrm{He}$ is an associate member of Board of Engineering Malaysia (BEM).

${ }^{4}$ Nur Azam Badarulzaman received his Bachelor degree and Master in Material Engineering from University of Science Malaysia (USM) in 1996 and 1999. He then continued his PhD in Ceramic in 2011 from USM. He did teaching in the Faculty of Mechanical Engineering in UTHM, Malaysia. He has been authored and/or coauthored various technical and review papers on the research in material science. His field of expertise is material science and technology. $\mathrm{He}$ is an associate member of Board of Engineering Malaysia (BEM).

\section{Funding}

Not applicable.

\section{Availability of data and materials}

All data generated or analyzed during this study are included in this article.

\section{Ethics approval and consent to participate}

This research does not contain any studies on human participants or animals performed by the author.

\section{Consent for publication}

Not applicable.

\section{Competing interests}

The authors declare that they have no competing interests.

\section{References}

1. Pandey, R., Sar, S. K., \& Bhui, A. K. (2012). Feasibility of Installing Rice Husk Power Plant in Chhatissgrah to Meet Sustainable Energy Demands. International Journal of Advanced Engineering Research and Studies.

2. Noor Syuhadah, S., \& Rohasliney, H. (2012). Rice Husk as biosorbent: A Review. Health and the Environment Journal, 3(1), 89-95.

3. Y. Li, X. Ding, Y. Guao, L. Wang, X. Ma, Z. W. (2017). A new method of comprehensive utilization of rice husk. $J$. Hazard Mater, (186), 2151-2156.

4. Gutiérrez, S., Philippi, C., Kreimerman, R., Ures, P., Torres, A. I. (2017). Survey of available biomass in Uruguay usable as a raw material in chemical production. VI Chemical Engineering Meeting, Montevideo, Uruguay. 
5. Kumar, S., Sangwan, P., Dhankhar, R., Mor, V., Bidra, S. (2013). Utilization of rice husk and their ash: a review. Research Journal of Chemical and Environmental Sciences, 1(5), 126-129.

6. Zhang, H., Zhao, X., Ding, X., Lei, H., Chen, X., An, D. Wang, Z. (2010). A study on the consecutive preparation of d-xylose and pure superfine silica from rice husk. Bioresource Technology, 101(4), 1263-1267.

7. Lacuesta, J., Beatriz, I., Sobhana, L., Kronlund, D., Peltonen, J. et al. (2020). Rice Husk Bio-Chars as Adsorbent for Methylene Blue and Ethinylestradiol from Water. Journal of Renewable Materials, 8(3), 275-287.

8. Peres, E. C., Slaviero, J. C., Cunha, A. M., Hosseini-Bandegharaei, A., Dotto, G. L. (2018). Microwave synthesis of silica nanoparticles and its application for methylene blue adsorption. Journal of Environmental Chemical Engineering, 6(1), 649-659.

9. Nur Saadah Zainal, Zaleha Mohamad, Mohammad Sukri Mustapa, Nur Azam Badarulzaman, Zainathul Akhmar Salim Abdul Salim, and Mohd Idrus Masirin, "Study of Characteristics of Rice Husk and Silica Obtained from Rice Husk," International Journal of Chemical Engineering and Applications vol. 9, no. 5, pp. 158-162, 2018.

10. Zainal N.S., Mohamad Z., Mustapa M.S., Badarulzaman N.A., Zulkifli A.Z. (2020) Studies on Silica Produced from Original and Firing Rice Husk. In: Awang M., Emamian S., Yusof F. (eds) Advances in Material Sciences and Engineering. Lecture Notes in Mechanical Engineering. Springer, Singapore.

11. Ministry of Health. Drinking Water Quality Standard.

12. Bhatnagara, A., Sillanpää, M. (2010). Utilization of agro-industrial and municipal waste materials as potential adsorbents for water treatment-a review. Chemical Engineering Journal, 157(2-3), 277-296.

13. Weiting $\mathrm{Xu}$, Tommy Y.Lo, S. A. M. (2012). Microstructure and reactivity of rich husk ash. Construction and Building Materials, 29, 541-547.

14. Bakar, R. A., Yahya, R., \& Gan, S. N. (2016). Production of High Purity Amorphous Silica from Rice Husk. Procedia Chemistry, 19, 189-195.

15. Muhammadi, A., \& Tindyala M. Ahmad. (2015). Thermoanalytical studies on acid-treated rice husk and production of some silicon based ceramics from carbonised rice husk. Journal of Asian Ceramic Societies, 3(3), 311-316.

16. M.N. Mohd Sokri, T. Onishi, Y. Daiko, S. Honda, Y. I. (2015). Hydrophobicity of amorphous silica-based inorganicorganic hybrid materials derived from perhydropolysilazane chemically modified with alcohols. In Microphorous Mesoporous Mater, 215,183-190).

17. Li, C., \& Wang, C. (2012). Effects of sintering temperature on properties of porous mullite / corundum ceramics, 73 , 36-39.

18. Khadijah, S., Ha, M., Othman, D., Ismail, A. F., \& Rahman, M. A. (2018). Fabrication of low cost, green silica based ceramic hollow fi bre membrane prepared from waste rice husk for water filtration application, 44.

19. Sawao Honda, Yuuki Ogihara, Shinobu Hashimoto, Y. I. (2010). Thermal Shock Properties of Porous Alumina for Support Carrier of Hydrogen Membrane Materials. In Ceramic Engineering and Science Proceedings, 31(6), 127-137.

20. Yalcin N and Sevinc V. 2001. Studies on silica obtained from rice husk. Ceramics International, vol 27, pp. 219-24.

21. A. R. Bielefeldt, K. Kowalski, C. Schilling, S. Schreier, A. Kohler, R. S. S. 2010. Removal of virus to protozoan sized particles in pointof-use 
ceramic water filters. Water Research, 44(5), pp. 1482- 1488.

22. Zainal, N. S., Mohamad, Z., Mustapa, M. S., Badarulzaman, N. A., \& Zulkifli, A. Z. (2019). The Ability of Crystalline and Amorphous Silica from Rice Husk Ash to Perform Quality Hardness for Ceramic Water FiltrationMembrane. International Journal of Integrated Engineering, 11(5), 229-235.

23. A. Ayaliew Werkneh, B. Zimbelachew Medhanit, A. K. A., \& Damte, and J.

Y.2015. Physico-Chemical Analysis of Drinking Water Quality at Jigjiga City, Ethiopia. American Journal of Environmental Protection, 4(1), pp. 2932. 
Figures

OO, N1, C1, N2, C2

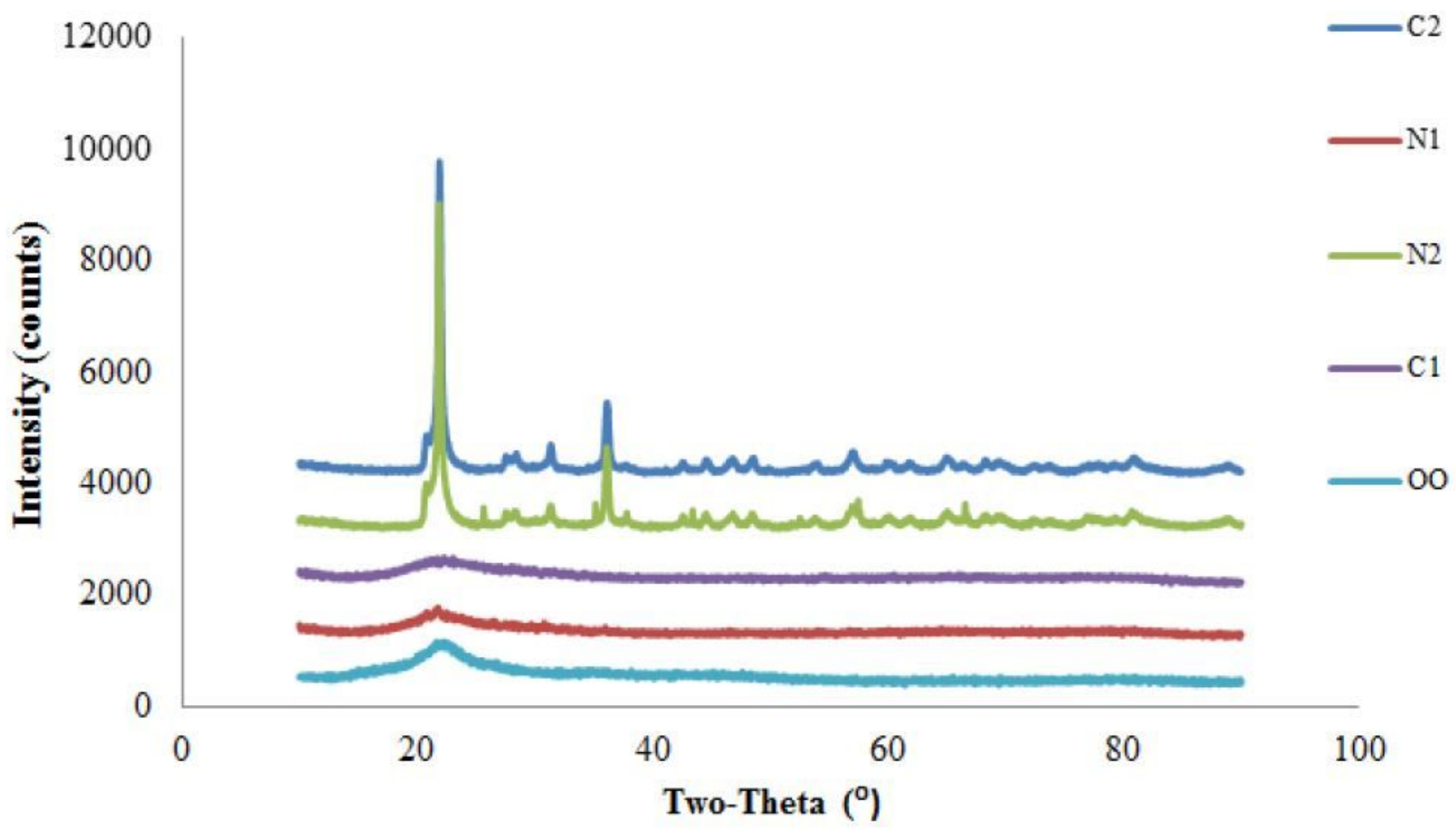

Figure 1

X-ray Diffraction (XRD) analysis result for samples. 


\section{OO, N1, C1, N2, C2}

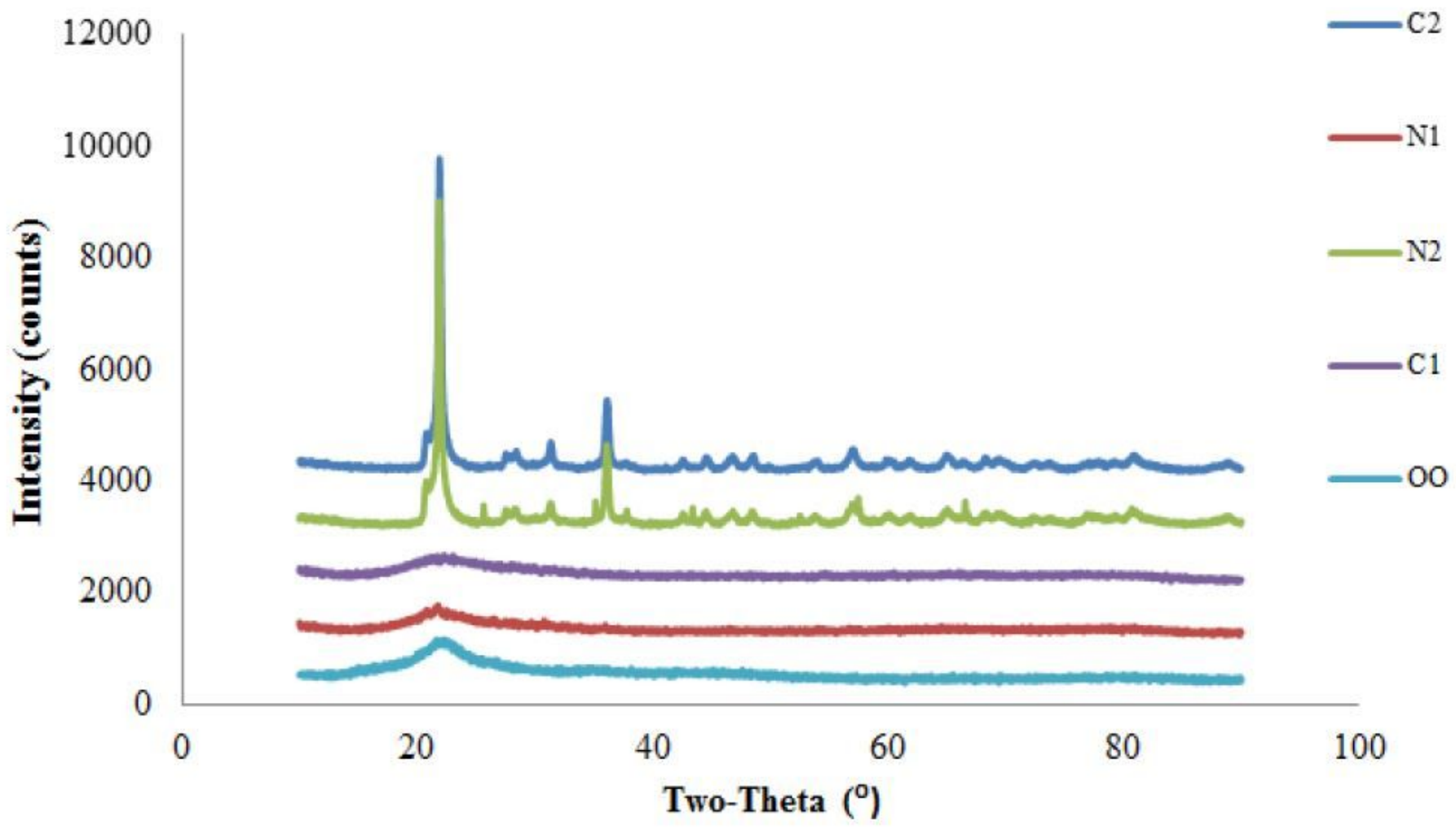

Figure 1

X-ray Diffraction (XRD) analysis result for samples. 


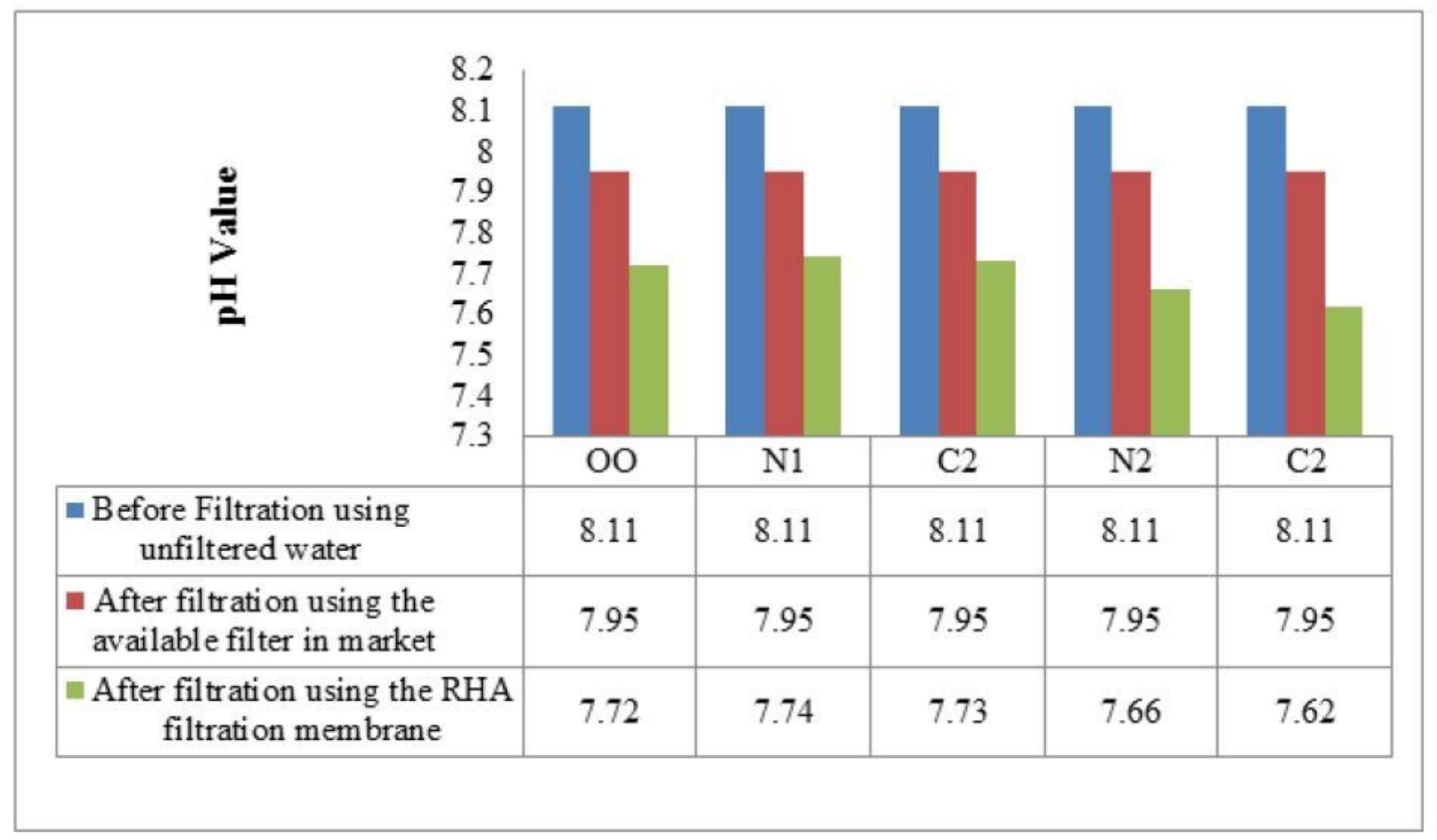

Figure 2

Bar chart of $\mathrm{pH}$ values for samples. 


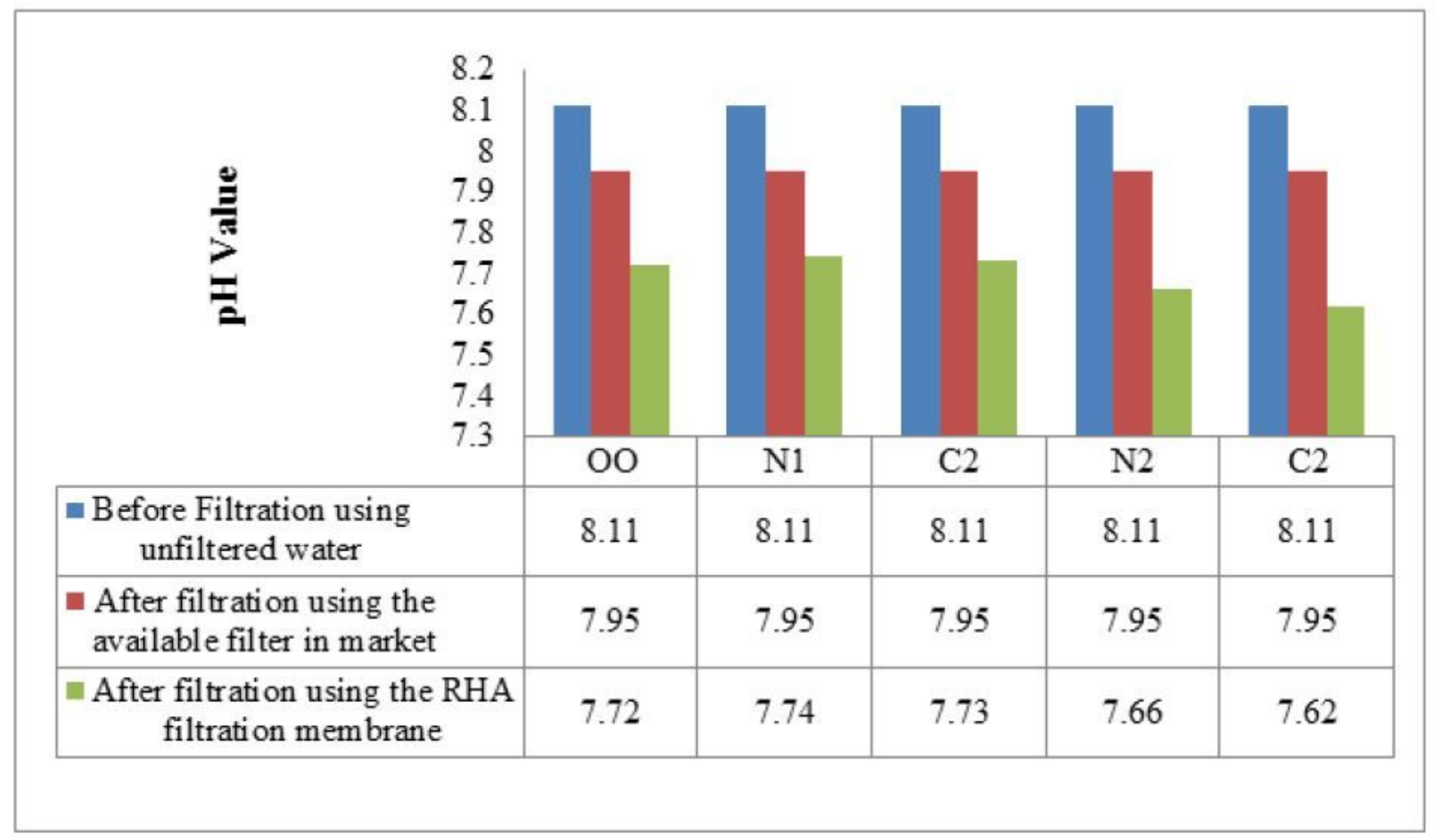

Figure 2

Bar chart of $\mathrm{pH}$ values for samples.

\section{Supplementary Files}

This is a list of supplementary files associated with this preprint. Click to download.

- BarChartph2.png

- BarChartph2.png

- XRDAnalysis2.png

- XRDAnalysis2.png 